Canadian University Music Review

Revue de musique des universités canadiennes

\title{
Beverley Diamond and Robert Witmer, eds. Canadian Music: Issues of Hegemony and Identity. Toronto: Canadian Scholars' Press, 1994. xi, 615 pp. ISBN 1-55130-031-1 (softcover)
}

\section{Joan Backus}

Volume 16, numéro 2, 1996

URI : https://id.erudit.org/iderudit/1014436ar

DOI : https://doi.org/10.7202/1014436ar

Aller au sommaire du numéro

\section{Éditeur(s)}

Canadian University Music Society / Société de musique des universités canadiennes

\section{ISSN}

0710-0353 (imprimé)

2291-2436 (numérique)

Découvrir la revue

Citer ce compte rendu

Backus, J. (1996). Compte rendu de [Beverley Diamond and Robert Witmer, eds. Canadian Music: Issues of Hegemony and Identity. Toronto: Canadian Scholars' Press, 1994. xi, 615 pp. ISBN 1-55130-031-1 (softcover)]. Canadian University Music Review / Revue de musique des universités canadiennes, 16(2), 139-142. https://doi.org/10.7202/1014436ar

All Rights Reserved (C Canadian University Music Society / Société de musique des universités canadiennes, 1996
Ce document est protégé par la loi sur le droit d'auteur. L’utilisation des services d'Érudit (y compris la reproduction) est assujettie à sa politique d'utilisation que vous pouvez consulter en ligne.

https://apropos.erudit.org/fr/usagers/politique-dutilisation/ 
différentes significations rattachées à un style, et qui pourrait notamment s'effectuer en tentant de répondre à la question : «Is it possible to develop a semiotic "lexicon" of musical attitudinal stances to lyrical content and, if so, by what processes and over what time scales would it change ?» (p. 187).

Une partie de la solution à ce problème pourrait se trouver dans l'analyse de rapports texte-musique d'œuvres appartenant à un même corpus, analyses alimentées par des données provenant de recherches sociologiques, perceptives et autres. De plus, les paramètres musicaux devraient inclure ceux qui émanent de l'utilisation de la technologie. Ces derniers devraient alors non seulement être considérés comme modulateurs d'une texture musicale, mais également comme des paramètres détenant des propriétés sémantiques (par exemple, l'effet d'écho) ${ }^{21}$. L'application des techniques d'analyse timbrale mentionnées plus haut pourrait de plus aider à préciser certains de ces rapports. Dans l'ensemble, donc, l'ouvrage de Moore s'avère très utile, notamment pour ce qui est de l'étude de l'évolution des différents styles associés au rock et de leurs composantes (surtout le progressif) et, comme on le voit, il suscite des réflexions susceptibles d'alimenter plusieurs débats et analyses.

Serge Lacasse

Beverley Diamond and Robert Witmer, eds. Canadian Music: Issues of Hegemony and Identity. Toronto: Canadian Scholars' Press, 1994. xi, 615 pp. ISBN 1-55130-031-1 (softcover).

I: Beverley Diamond, "Issues of Hegemony and Identity in Canadian Music"; II: Maria Tippett, "'An Identity of Tastes and Aspirations': Educating Performers and Their Audiences"; Marie-Thérèse Lefebvre, "The Role of the Church in the History of Musical Life in Quebec"; Nina De Shane, "'Multiethnic' Dance in Ontario: The Struggle over Hegemony"; J.L. Granatstein, "Culture and Scholarship: The First Ten Years of the Canada Council"; Carole H. Carpenter, "The Ethnicity Factor in Anglo-Canadian Folkloristics"; Beverley Diamond, "Narratives in Canadian Music History"; Jody Berland, "Radio Space and Industrial Time: The Case of Music Formats"; III: James Robbins, "What Can We Learn When They Sing, Eh? Ethnomusicology in the American State of Canada"; Line Grenier and Jocelyne Guilbault, “"Authority' Revisited: The 'Other' in Anthropology and Popular Music Studies"; R. Murray Schafer, "Canadian Culture: Colonial Culture"; Lucien Poirier, "A Canadian Music Style: Illusion and Reality"; John Lehr, "As Canadian As Possible ... under the Circumstances: Regional Myths, Images of Place and National Identity in Canadian Country Music"; Robert A. Wright, "'Dream, Comfort, Memory, Despair': Canadian Popular Musicians and the Dilemma of Nationalism, 19681972"; IV: Norman Buchignani, "Canadian Ethnic Research and Multiculturalism"; Regula Burckhardt Quereshi, "Focus on Ethnic Music"; Robert B. Klymasz, "From

21 Au sujet de l'effet d'écho, voir John Hollander, The Figure of Echo: A Mode of Allusion in Milton and After (Berkeley, Los Angeles et Londres : University of California Press, 1981) et Joseph Loewenstein, Responsive Readings : Versions of Echo in Pastoral, Epic, and the Jonsonian Masque (New Haven et Londres : Yale University Press, 1984). Bien que ces ouvrages traitent de poésie, on y trouve de nombreux renseignements au sujet de l'écho comme phénomène acoustique ayant une portée sémantique, et dont l'« étymologie » serait rattachée, entre autres, à une longue tradition mythographique. 
Immigrant to Ethnic Folklore: A Canadian View of Process and Transition"; Annemarie Gallaugher, "Trinbago North: Calypso Culture in Toronto"; Alfred Young Man, "The Metaphysics of North American Indian Art"; Michael Kennedy and Robert Campbell, "The Kennedy-Campbell Debate"; Neil V. Rosenberg, "Ethnicity and Class: Black Country Musicians in the Maritimes"; Frederick A. Hall, "Musical Yankees and Tories in Maritime Settlements of 18th-Century Canada"; $R$. Brunton, J. Overton, and J. Sacouman, "Uneven Underdevelopment and Song: Culture and Development in the Maritimes"; Andra McCartney, "Inventing Metaphors and Metaphors for Invention: Women Composers' Voices in the Discourse of Electroacoustic Music"; V: Steve Wingfield, "From Culture Shock to Cultural Exchange: Trichy Sankaran, Karnatak Musician in Transition"; Suzanne Meyers Sawa, "The Odyssey of Dahlia Obadia: Morocco, Israel, Canada"; Gordon E. Smith, "Lee Cremo: Narratives about a Micmac Fiddler"; Framziska von Rosen, "'Thunder, That's Our Ancestors Drumming': Music As Experienced by a Micmac Elder”; Patrick Hutchinson, "The Work and Words of Piping."

If it is true, as Linda Hutcheon and others have suggested, irony is a central and recurring image in our postmodern and postcolonial Canada, we might well take particular pleasure in the marked upswing of publications on Canadian music that have appeared in the past few years. Even as the country seems to be careering towards self-destruction, Canadian musicology appears to be finding its own voice. This new-found confidence is especially evident in the collection of essays titled Canadian Music: Issues of Hegemony and Identity, edited by Beverley Diamond and Robert Witmer. Here we have not only another useful anthology for the music historian and teacher but, more significantly, a new model for the writing of Canadian music history.

In editing this collection, Diamond and Witmer have assembled a variety of essays (many of which have been previously published) that collectively serve to address the writing of music history in Canada. The essays are grouped into four broad categories that explore issues relating to Canadian music-specifically, issues of power/control and issues of identity. Obviously these issues are not mutually exclusive, but rather play back and forth against one another, and this is precisely what the essays in the anthology are made to do. Even within each of the four categories, the essays do not collectively generate a linear unfolding of ideas ultimately leading to a comprehensive understanding of the issue; instead, the cumulative effect is achieved through the bold juxtaposition of a broad range of perspectives. There is no attempt to fill all the gaps, to provide a comfortable and comforting blanket account of any single aspect of Canadian music, but rather an exploration of possibilities, a presentation of the range of critical paradigms that can be put to use in the exploring and the writing of a history. Open-ended rather than exhaustive, the anthology opens up and establishes the ground for a great number of future studies. Indeed, it might best be taken as a collective challenge to Canadian music historians.

Beverley Diamond's introduction, "Issues of Hegemony and Identity in Canadian Music," along with the introductory essays at the beginning of each section of the anthology, provide a valuable contextualization of the issues at hand. Each of these introductory sections offers both a critical overview of the 
subject and an annotated guide to further readings. When supplemented by the lists of references that follow many of the essays in the collection, these annotated guides generate a useful and broad-ranging bibliography.

Given the editors' concern to address issues of power and control in the structuring of Canadian music history, it is not surprising that they adopt a pointedly self-conscious stance. Few assumptions are left unchallenged in their introductory essays. In the introduction to the anthology as a whole, for example, Diamond singles out for discussion what she describes as three "deceptively straightforward words" in the title. "Hegemony" and "identity," terms so often bandied about in postmodern academic discourse, obviously necessitate the careful reflection she accords them. The third word singled out for consideration, though, is "Canadian," a term whose meaning many readers would not think to question. As Diamond points out, however, the use of "Canadian" implies a reflection on the fragile conceptions of nation and. nationalism, terms which are highly problematic, especially in our postcolonial and multicultural society. Following the path established by Diamond in this introductory essay, the reader, in the course of perusing the anthology, is challenged to ponder the meanings of the three terms. A careful reading of the anthology cannot help but create an indelible impression of the complex relationships between the notions of hegemony, identity, and Canadian, and of the various ways and levels in which these ideas intersect.

Also striking is the wide range of topics explored in the essays. From folk to electroacoustic, from calypso culture in Toronto to Micmac fiddlers in Nova Scotia, from ethnic traditions to broadcasting policy, this anthology ranges very far indeed. Nor are the topics confined to music. For example, historian Jack Granatstein writes on the early years of the Canada Council, and anthropologist Norman Buchignani provides a rich account of ethnic research and multiculturalism in Canada. This fundamental interdisciplinary approach allows those trained in traditional musicology-a field that can be somewhat parochial-to be challenged by materials and critical approaches that may be new to them. Because so many of the articles have previously been published, the anthology can also serve to point readers towards a wider reading of the journals and books in which the essays first appeared.

It is both surprising and refreshing to observe the rather modest attention given to the CanMus mainstream. Murray Schafer's classic polemic "Canadian Culture: Colonial Culture" is reprinted here, but otherwise there is scant reference to those composers whose names usually grace the texts on Canadian music. Instead, there is an obvious celebration of the marginal voices-explorations of musics and musicians that dwell outside the mainstream. By undermining, however subtly, the dominance of "high art" musical culture, the editors throw into relief the delicate relationships between the centre and the margins, provoking a need to revisit Northrop Frye's celebrated conundrum "Where is here?"

In his collection of essays titled Producing Marginality: Theatre and Criticism in Canada, theatre critic Robert Wallace has argued that "those who control the methods by which people create and express their culture in regions 
and locales deemed marginal by 'the centre'-no matter how the centre is defined-also control the ways by which they create and authenticate their existence as individuals." 22 Diamond and Witmer are obviously acutely aware of their great responsibility in this assumption of cultural authority: as editors they are inevitably and inescapably in a position of control. Thus it is curious (at least to this soul observing from the Western margin of the country) that while there is representation-undoubtedly carefully considered-from both Western and Atlantic provinces as well as from Quebec, there is such a marked emphasis on the view from Ontario, or, shall we say, from the centre. Even giving recognition to notions of representation by population, it is still notable that seventeen of the thirty-three contributors are Ontario residents, and of those, nine (including the editors) teach at York University. One could argue that a Yorkocentric view is an almost inevitable consequence of the significant and vital work being done there in Canadian studies and interdisciplinary research, yet we are still advised, I think, to reflect once again on the problems and paradoxes inherent in the ways cultural discourse is defined and created.

Implicit in the strength of this anthology-that is, its vast scope and its profusion of intellectual perspectives-is its basic weakness: the tremendous variety of approaches is paralleled by a disparity in the quality of the articles. Stated simply, some of the essays are much better than others. This is inevitable in any anthology, of course, but at times it appears that the concept of the book is more significant than some of the articles themselves.

Obviously, if the essays themselves present such a varied range of critical perspectives, there is a danger that an anthology of this size (it runs to over 600 pages) will lack a cohesive focus, a central defined framework that holds the diverse ideas together. But, ironically, in this lies the most exciting feature of this text, for it acts as a mirror of the Canadian identity. At times fragmented and fragmentary, absorbed with the problems of defining and expressing its identity, wrestling with the sensitive issues of power and control, of margins and centre, and ultimately attempting to be inclusive and hospitable to all comers: these are the very issues that absorb the country as a whole. Beverley Diamond and Robert Witmer have successfully challenged our understanding of how these larger concerns are played out in the act of writing about our diverse musical traditions. As a result, this anthology represents a valuable step towards the definition and practice of a distinctive Canadian musicology.

Joan Backus

Joseph Kerman. Write All These Down: Essays on Music. Berkeley: University of California Press, 1994. xii, 359 pp. ISBN 0-520-08355-5 (hardcover).

I. Criticism: "A Profile for American Musicology"; "How We Got into Analysis, and How to Get Out"; "A Few Canonic Variations"; "Critics and Classics"; II. Byrd, Tallis, Alfonso Ferrabosco: "William Byrd and Elizabethan Catholicism"; "Byrd,

22Robert Wallace, Producing Marginality: Theatre and Criticism in Canada (Saskatoon: Fifth House Publishers, 1990), 30. 